\title{
Macroeconomic Determinants of Entrepreneurship in Emerging and Developing Countries
}

\author{
Kamilia Loukil \\ Faculty of Economics and Management, Sfax University \\ Airport road km 4, 3018, Sfax, Tunisia \\ E-mail: kamilia.loukil@gmail.com
}

Received: July 2, 2019 Accepted: July 31, 2019 Published: October 27, 2019

doi:10.5296/ber.v9i4.15713 URL: https://doi.org/10.5296/ber.v9i4.15713

\begin{abstract}
This study examines which factors in macroeconomic environment can stimulate entrepreneurial activity in emerging and developing countries. We employ a System Generalized Method of Moments (System GMM) technique to examine determinants of entrepreneurial activity for a panel of 30 countries during the period 2004-2012. Findings show the importance of demand and institutional framework for new business entry. Moreover, we find that entrepreneurship is an autoregressive process.
\end{abstract}

Keywords: Entrepreneurship, Macroeconomic environment, Demand, Unemployment, Financial development, Institutions, Emerging and developing countries

\section{Introduction}

Entrepreneurship is increasingly seen as a key determinant of economic development (Baumol 1990; Wennekers and Thurik 1999; Minniti and Lévesque 2008). According to Baumol (1990) and Acs (2006), entrepreneurship fosters innovation and enhances employment creation.

As it has many benefits to the society, many studies focused on identifying its national determinants. Researchers have considered economic, institutional and psychological determinants of entrepreneurial activity. In this contribution we examine which factors in macroeconomic environment can stimulate entrepreneurial activity.

The objective of this paper is to highlight how the the economic and institutional frameworks affect the entrepreneurship level in emerging and developing countries. This issue is very important for developing countries as their current global context is dominated by globalization, a phenomenon that increases both the opportunities offered and the challenges 
to be met. An example of opportunities is the possibility of modernizing traditional activities thanks to new technologies. The challenges are accentuated as the development process requires a considerable amount of knowledge and a developed entrepreneurial spirit.

Our study aims to enrich existing literature by examining the determinants of entrepreneurship for 30 countries between 2004 and 2012. To estimate our dynamic panel data model, we employ a System Generalized Method of Moments (System GMM) technique. Our estimated results show a positive and significant effects of demand and institutions on entrepreneurship.

The rest of the paper is organized as follows: In Section 2 we discuss theoretical issues and empirical results relative to previous studies. In Section 3 we introduce the data and empirical methodology. Our empirical findings are presented and discussed in Section 4. Section 5 concludes.

\section{Determinants of Entrepreneurship: Literature Review}

Literature on entrepreneurship identifies four macroeconomic factors affecting entrepreneurship: demand, unemployment, financial development and institutional framework (Makosso, 2013).

One determinant of entrepreneurship that has galvanized a lot of theoretical and empirical attention is demand. The increase in demand for goods and services, attributed to population growth, per capita income growth and changing tastes, leads to market expansion (Weneker et al., 2005) and is therefore associated with a high rate of firm creation (Gaygisiz and Köksal, 2003). The reason for this is that market expansion creates profit opportunities (Brusco, 1982).

Two variables of demand growth were employed. The first was an indicator of growth in regional Gross Domestic Product. The second was a measure of population growth.

The relationship between per capita GDP and entrepreneurship is not clear. Ovaska and Sobel (2004) find that there is not a significant effect of this metric on the number of new enterprises per 1000 inhabitants. Results of Parker and Robson (2004) indicate that per capita GDP enhances entrepreneurship. Other authors like Noorderhaven et al. (2004) and Bjornskov and Foss (2008) show that GDP per capita reduces new firm formation.

For the second indicator of demand, many studies find a positive impact of population growth on entrepreneurship (Audretsch and Fritsch, 1994; Reynolds et al., 1994, 1995; Santarelli and Tran, 2012). While Sutaria and Hicks (2004) find a negative effect.

The literature emphasizes the level of financial development as a factor affecting the new firm formation. The probability of individuals becoming entrepreneurs is increasingly higher with the degree of their wealth and the volume of assets they control (Evans and Leighton, 1989). Capital is an important determinant of business formation because it influences not only the ability of firms to penetrate the market but also their ex post performance. Empirical studies have shown that sufficient financial resources allow new firms to survive (Kauermann et al., 2005) and grow (Bamford et al., 2004). 
Several empirical studies have shown the positive effect of financial development on the formation of new firms. For example, Aghion et al. (2007) used enterprise-level data in a sample of 16 OECD countries, countries in transition and Latin American countries in the 1990s. They found that a higher level of financial development reinforces the entry of new firms in sectors that rely on external financing. Ghani et al. (2014) verified that the robustness of the banking environment is associated with high rates of new firm entries in India. Klapper et al. (2010) found that ease of access to financing in one country is one factor, among others, of encouraging entrepreneurship. Naudé et al. (2008) conducted a study to empirically identify the determinants of strat-up rates in South Africa. They found that access to finance plays an important role in the formation of such enterprises.

Unemlpoyment is one of the documented determinants of entrepreneurship. The nature of this relation is however ambiguous. The 'Push hypothesis' suggests that the impact would be positive. Oxenfeldt (1943) underlined that the self-employment may be a good solution for unemployed people. In contrary, the 'pull hypothesis' indicates that the impact is negative. Lucas (1978) and Jovanovic (1982) suggest that the unemployed has a fairly low level of human capital that prevents him/her from creating a new firm.

Empirical evidence confirms this contrast. Some empirical works have found that unemployment increases entrepreneurial activities (Audretsch et al., 2001; Thurik et al, 2008; Evans and Leighton, 1990). Some others have shown that unemployment reduces new firm formation (Reynolds et al., 1995; Garofoli, 1994). In other studies, the effect of the unemployment rate on entrepreneurship has been found to be slightly significant or insignificant (Santarelli and Tran, 2012; Calà et al., 2016; Naudé et al., 2008).

Institutions are another documented determinant of entrepreneurship. According to North (1991), institutions are the humanly devised constraints that structure political, economic and social interaction. Entrepreneurs adapt their actions to the opportunities and threats of the institutional framework. Baumol (1993) analyzes the types of entrepreneurship that appear in various institutional environments. He distinguishes between different categories of entrepreneurship: productive, unproductive and destructive entrepreneurship.

Johnson et al. (2002) find that weak property rights and legal systems hinder entry of new enterprises. Desai et al. (2003) find that many entrepreneurial activities take place in european countries with less corruption and better property rights.

\section{Methodology}

\subsection{Sample Description}

Our sample includes 30 emerging and developing countries 1 . The period of study is from

\footnotetext{
${ }^{1}$ In this paper, we adopt the ranking of countries according to the report of the International Monetary Fund (IMF, 2012), which classifies countries into two categories: "Advanced Economies" and "Emerging and Developing Economies." Countries included in our sample are: Argentina, Bolivia, Brazil, Bulgaria, Chile, Colombia, Costa Rica, Croatia, Egypt, El Salvador, Hungary, Indonesia, Jamaica, Jordan, Latvia, Lithuania, Malaysia, Mexico, Morocco, Panama, Perou, Philippines, Poland, Romania, Russia, Thailand, Tunisia, Turkey. Ukraine, Uruguay.
} 
2004 to 2012.

\subsection{Measurement of Variables}

\subsubsection{Dependent Variable}

According to Klapper et al. (2010), entrepreneurship is identified as initiating economic activities via the legal process of starting a business. This definition implies that the rate of new business entry is an adequate measure of entrepreneurship in a country. In particular, for this paper, the entrepreneurship level (ENT) is measured by the new business entry density, which is defined as the number of newly registered limited liability corporations per calendar year, normalized by working age population. The same measure was used by Klapper et al. (2010), Klapper and Love (2011) and Hartwell (2014). The data are obtained from the World Bank's World Development Indicators.

\subsubsection{Independent Variables}

According to the literature on entrepreneurship, two metrics are employed for the growth of demand: GDP per capita (GDP) and population growth (POPG).

The data on PPP converted GDP per capita, at 2005 constant prices come from Penn World Table. Data on population growth are obtained from the World Bank's World Development Indicators.

To measure the unemployment level, we use the variable (UNEMP) which refers to the share of the labor force that is without work but available for and seeking employment.

Financial development (FD) is measured by domestic credit to private sector as share of GDP.

Data on both unemployment and financial development come from the World Bank's World Development Indicators (WDI).

The institutional framework is measured by the Economic Freedom Index of the Economic Report (Gwartney et al., 2014) taking a value between 1 and 10 (EF).

All variables are transformed in natural logarithm. Summary statistics for the variables are given in Table 1.

Table 1. Summary statistics

\begin{tabular}{|l|l|l|l|l|l|}
\hline & Mean & Median & Stand. dev & Minimum & Maximum \\
\hline ENT & 2.911 & 1.278 & 3.768 & 0.085 & 21.487 \\
\hline GDP & 7323.799 & 7385.142 & 3774.886 & 1676.217 & 14782.67 \\
\hline POPG & 0.721 & 1.03 & 1.095 & -2.258 & 4.259 \\
\hline FD & 50.39 & 43.868 & 26.259 & 9.682 & 136.301 \\
\hline UNEMP & 8.509 & 7.9 & 3.741 & 0.7 & 22.8 \\
\hline EF & 6.916 & 6.935 & 0.531 & 5.15 & 8.01 \\
\hline
\end{tabular}

\subsection{Econometric Estimation}

To estimate our model, we employ the Generalised Method of Moments (GMM). This 
method is adequate for our case in which as mentioned by Mileva (2007), the panel dataset has a short time dimension $(\mathrm{T}=9)$ and a larger country dimension $(\mathrm{N}=30)$. Moreover, Bond (2002) points out that this method permits to deal with omitted dynamics in static panel data models, owing to the ignorance of the impacts of lagged values of the dependent variable. Indeed, Holcombe (1998) notes that entrepreneurship generates more entrepreneurship. The business birth rate observed in the last period must explain the present rate.

There are two types of GMM estimators (difference and system).

Arellano and Bond (1991) estimation starts by transforming all regressors, usually by differencing, and uses the Generalized Method of Moments. It is called "difference GMM."

The Blundell-Bond (1998) estimator augments Arellano-Bond by making an additional assumption, that first differences of instrumenting variables are uncorrelated with the fixed effects. This allows the introduction of more instruments, and can dramatically improve efficiency. It is known as "system GMM."

To estimate our empirical model, we use the system GMM technique.

Blundell and Bond (1998) point out that the instruments of the system-GMM estimator include the available lags in difference of the endogenous variables, the strictly exogenous regressors and the lagged values of the dependent variable.

Our dynamic panel data model is represented as follow:

$$
\begin{gathered}
\mathrm{ENT}_{\mathrm{it}}=\beta 0+\beta 1 \mathrm{ENT}_{\mathrm{it}-1}+\beta 2 \mathrm{GDP}_{\mathrm{it}}+\beta 3 \mathrm{POPG}_{\mathrm{it}}+\beta 4 \mathrm{FD}_{\mathrm{it}}+\beta 5 \mathrm{UNEMP}_{\mathrm{it}}+\beta 5 \mathrm{EF}_{\text {it }} \\
+\mu_{\mathrm{i}}+\varepsilon_{\mathrm{it}}
\end{gathered}
$$

$\mathrm{i}=1, . ., \mathrm{N}$ denotes the country (in our study, $\mathrm{N}=30$ ) and $\mathrm{t}=1, \ldots \mathrm{T}$ denotes the time period (in our study, $\mathrm{T}=9$ ).

ENT is the entrepreneurship level, GDP is the GDP per capita, POPG is the population growth rate, FD is the level of financial development, UNEMP is the unemployment rate, EF is the economic freedom index, $\mu$ is an unobserved country-specific effect and $\varepsilon$ is the time-varying error term.

Our estimations have been performed using the xtabond 2 command in Stata 12.

\section{Findings}

Findings are presented in Table 2 bellow.

Consistency of the GMM estimator depends on the validity of instruments. To address this issue, we consider three specification tests: the first is the Hansen test of over-identifying restrictions. The second and third tests are the first and second-order autocorrelation test for error term, which tests the null hypothesis according to which there is no autocorrelation. As shown in Table 2, the p-value of Hansen test $(1.000>0.05)$ indicates that the used instruments are valid. The p-values of Arrelano-Bond test are 0.1 for AR(1) and 0.053 for $\operatorname{AR}(2)$, both superior than 0.05. Therefore, there is no autocorrelation of error term. Accordingly, we can conclude that the system GMM estimation is robust and appropriate. 
Based on the system GMM estimation, we find evidence of positive effect on entrepreneurship of one year lagged value of new business entry density at $1 \%$ level. Result indicates that $10 \%$ increase in entrepreneurship in the this year will improve the level of entrepreneurial activity by $7.72 \%$ the next year. Our result confirms the hypothesis of Holcombe (1998): entrepreneurship generates more entrepreneurship.

Among the economic determinants studied in this paper, we find that demand and institutions are the main determinants of entrepreneurship. Indeed, the coefficient relative to GDP is positive (0.306) and significant at the $1 \%$ threshold. This means that a $10 \%$ increase in GDP per capita is accompanied by an increase of $3.06 \%$ in the new firm entry density. The effect of population growth is also positive and significant at $10 \%$. These results show the importance of the demand for the entrepreneurial activity in the countries observed. They corroborate those found by Parker and Robson (2004) and Santarelli and Tran (2012).

The effect of institutional framework is positive (1.769) and significant at 5\%. This result is coherent with those of Johnson et al. (2002) and Desai et al. (2003) who conducted their studies in Europe. The main conclusion from such finding is that, whatever the region, a favourable institutional environment spurs the business creation.

The coefficient relative to unemployment rate is negative (-0.074) and significant at $1 \%$. Thus, we confirm the "pull hypothesis" which suggests that the unemployed person is incompetent to start a new firm. Moreover, our result implies that higher unemployment reflects a reduction in demand. Our result corroborates findings of Reynolds et al. (1995) for the case of USA and Garofoli (1994) for the case of Italy. By contrast, it is inconsistent with Thurik et al. (2008)'s study which focuses on a set of developed economies.

Financial development has not a significant impact on entrepreneurship. This means that an improvement of the share in GDP of credit to private sector does not increase the level of new business entry. Our result is inconsistent with Aghion et al. (2007) and Ghani et al. (2014).

A possible explanation for our finding is that well-developed financial system stimulate more existing firms to hire new workers. Individuals who are in a situation of unemployment prefer to be employees rather than employers.

Table 2. System GMM model regression

\begin{tabular}{|l|l|l|}
\hline \multirow{2}{*}{ Independent variables } & \multicolumn{2}{|l|}{ Dependant variable: ENT $=$ new business entry density } \\
\cline { 2 - 3 } & Coefficients $\beta$ & Standard Errors \\
\hline Constant & -5.301 & $1.182^{* * *}$ \\
\hline L.ENT & 0.772 & $0.077^{* * *}$ \\
\hline GDP & 0.306 & $0.076^{* * *}$ \\
\hline POPG & 0.502 & $0.3^{*}$ \\
\hline FD & -0.166 & 0.111 \\
\hline UNEMP & -0.074 & $0.026^{* * *}$ \\
\hline EF & 1.769 & $0.854^{* *}$ \\
\hline Observations & 210 & \\
\hline
\end{tabular}




\begin{tabular}{|l|l|}
\hline Number of instruments & 77 \\
\hline Hansen J test (p-value) & 1.000 \\
\hline AR(1) test (p-value) & 0.1 \\
\hline AR(2) test (p-value) & 0.053 \\
\hline
\end{tabular}

Coefficients and standard errors are given in this table.

$*, * *, * * *$ : coefficients are significant at $10 \%, 5 \%$ and $1 \%$.

All variables are in natural logarithm.

L.ENT, GDP, POPG, FD, UNEMP and EF denote respectively: lag of entrepreneurship, GDP per capita, population growth, domestic credit to private sector (\%GDP), unemployment rate and Economic Freedom index.

\section{Conclusion}

The aim of this study was to evaluate the role of macroeconomic factors in entrepreneurship in emerging and developing countries. From the relevant literature, it appears that demand, financial development, unemployment and institutional framework are the main determinants of entrepreneurship. The empirical evidence shows that both the demand and institutions spur new firm entry. While unemployment discourages it. Financial development does not affect significantly the entrepreneurial activity. Moreover, we find that the new firm formation in developing and emerging countries is an autoregressive process: entrepreneurship generarates more entrepreneurship. For future research, we suggest studying the origin of this process: is it due to the transmission of the entrepreneurial culture within the family, or the existence of the effects of networks causing cognitive spillovers, or the existence of public policies more favourable to the creation of businesses?

\section{References}

Acs, Z. (2006). Start-ups and entry barriers: Small and medium-sized firms population dynamics. In M. Casson, B. Yeung, A. Basu, \& N. Wadeson (Eds), The Oxford handbook of entrepreneurship (pp. 194-224). Oxford University Press.

Aghion, P., Fally, T., \& Scarpetta, S. (2007). Credit constraints as a barrier to the entry and post-entry growth of firms. Economic Policy, 22(52), 731-779.

https://doi.org/10.1111/j.1468-0327.2007.00190.x

Arellano, M., \& Bond, S. (1991). Some tests of specification for panel data: Monte Carlo evidence and an application to employment equations. The Review of Economic Studies, 58, 277-297. https://doi.org/10.2307/2297968

Audretsch, D. B., \& Fritsch, M. (1994). The geography of firm births in Germany. Regional Studies, 28, 359-365. https://doi.org/10.1080/00343409412331348326

Audretsch, D. B., Carree, M. A., \& Thurik, A. R. (2001). Does entrepreneurship reduce unemployment? Tinbergen Institute Discussion Paper, TI 2001-074/3, Rotterdam: Tinbergen Institute. 
Bamford, C. E., Dean, T. J., \& Douglas, T. J. (2004). The temporal nature of growth determinants in new bank foundings: Implications for new venture research design. Journal of Business Venturing, 19(6), 899-919. https://doi.org/10.1016/j.jbusvent.2003.05.001

Baumol, W. (1993). Entrepreneurship, Management, and the Structure of Payoffs. Cambridge London: The MIT Press.

Baumol, W. J. (1990). Entrepreneurship : productive, unproductive and destructive. Journal of Political Economy, 98(5), 893-921. https://doi.org/10.1086/261712

Bjornskov, C., \& Foss, N. (2008). Economic freedom and entrepreneurial activity: Some cross-country evidence. Public Choice, 134, 307-328.

https://doi.org/10.1007/s11127-007-9229-y

Blundell, R., \& Bond, S. (1998). Initial conditions and moment restrictions in dynamic panel data models. Journal of Econometrics, Elsevier, 87(1), 115-143.

https://doi.org/10.1016/S0304-4076(98)00009-8

Bond, S. R. (2002). Dynamic panel data models: A guide to micro data methods and practice. Portuguese Economic Journal, 1, 141-162. https://doi.org/10.1007/s10258-002-0009-9

Brusco, S. (1982). The Emillian model: productive decentralization and social integration. Cambridge Journal of Economics, 6, 167-184.

Calà, C. D., Manjón-Antolín, M. C., \& Arauzo-Carod, J. M. (2016). Regional determinants of firm entry in a developing country. Papers in Regional Science 95(2), 259-279. https://doi.org/10.1111/pirs.12128

Desai, M., Gompers, P., \& Lerner, J. (2003). Institutions, capital constraints, and entrepreneurial firm dynamics: evidence from Europe. NBER Working Paper, 10165.

Evans, D. S., \& Leighton, L. S. (1990). Small business formation by unemployed and employed workers. Small Business Economics, 2, 319-330.

https://doi.org/10.1007/BF00401628

Evans, D. S., \& Leighton, L. S. (1989). Some empirical aspects of entrepreneurship. American Economic Review, 79(3), 519-533. https://doi.org/10.1007/978-94-015-7854-7_6

Garofoli, G. (1994). New firm formation and regional development: The Italian case. Regional Studies, 28, 381-394. https://doi.org/10.1080/00343409412331348346

Gaygisiz, E., \& Koksal, M. Y. (2003). Regional variations in new firm formation in Turkey: Cross-section panel data evidence. ERC Working Papers in Economics, 03/08, September.

Ghani, E., Kerr, W., \& O'connell, S. (2014). Spatial determinants of entrepreneurship in India. Regional Studies, 48(6), 1071-1089. https://doi.org/10.1080/00343404.2013.839869

Gwartney, J., Lawson, R., \& Hall, J. (2014). Economic freedom dataset. In Economic Freedom of the World: 2014 Annual Report. Fraser Institut (Ed.).

Hartwell, C. A. (2014). Capital controls and the determinants of entrepreneurship. Finance a 
úvěr-Czech Journal of Economics and Finance, 64(6), 434-457.

Holcombe, R. (1998). Entrepreneurship and economic growth. The Quarterly Journal of Austrian Economics, 1(2), 45-62. https://doi.org/10.1007/s12113-998-1008-1

IMF. (2012). Growth resuming, dangers remain, World Economic Outlook April 2012.

Johnson, S., McMillan, J., \& Woodruff, C. (2002). Property rights and finance. The American Economic Review, 92(5), 1335-1356. https://doi.org/10.1257/000282802762024539

Jovanovic, B. (1982). Selection and evolution of industry. Econometrica, 50, 649-670.

https://doi.org/10.2307/1912606

Kauermann, G., Tutz, G., \& Bruderl, J. (2005). The survival of newly founded firms: A case-study into varying-coefficient models. Journal Of The Royal Statistical Society Series A-Statistics in Society, 168(1), 145-158. https://doi.org/10.1111/j.1467-985X.2004.00341.x

Klapper, L., \& Love, I. (2011). The impact of the financial crisis on new firm registration. Economics Letters, 113(1), 1-4. https://doi.org/10.1016/j.econlet.2011.05.048

Klapper, L., Amit, R., \& Guillén, M.F. (2010). Entrepreneurship and firm formation across countries. In J. Lerner, \& A. Schoar (Eds.), International Differences in Entrepreneurship (pp.129-158). Chicago, University of Chicago Press.

Lucas, R. E. (1978). On the size distribution of business firms. Bell Journal of Economics, 9, 508-523. https://doi.org/10.2307/3003596

Makosso, B. (2013). L'entrepreneuriat dans un contexte d'adversité : une analyse des déterminants macroéconomiques de la création de nouvelles entreprises au Congo-Brazzaville. Revue de l'Entrepreneuriat, 12(3), 11-31.

https://doi.org/10.3917/entre.123.0011

Mileva, E. (2007). Using Arellano - Bond dynamic panel GMM estimators in Stata. Tutorial with examples using Stata 9.0 (xtabond and xtabond2). Working Paper.

Minniti, M., \& Lévesque, M. (2008). Recent development in the economics of entrepreneurship. Journal of Business Venturing, 3(6), 603-612.

https://doi.org/10.1016/j.jbusvent.2008.01.001

Naudé, W., Gries, T., Wood, E., \& Meintjies, A. (2008). Regional determinants of entrepreneurial start-ups in a developing country. Entrepreneurship \& Regional Development: An International Journal, 20(2), 111-124. https://doi.org/10.1080/08985620701631498

Noorderhaven, N., Thurik, R., Wennekers, S., \& van Stel, A. (2004). The role of dissatisfaction and per capita income in explaining self-employment across 15 European Countries. Entrepreneurship Theory and Practice, 28, 447-466.

https://doi.org/10.1111/j.1540-6520.2004.00057.x

North, D. C. (1991). Institutions. The Journal of Economic Perspectives, 5(1), 97-112. https://doi.org/10.1257/jep.5.1.97 


\section{Macrothink}

Business and Economic Research ISSN 2162-4860 2019, Vol. 9, No. 4

Ovaska, T., \& Sobel, R.S. (2004). Entrepreneurship in Post-Socialist Economies. Department of Economics Working Papers, 04-06, West Virginia University.

Oxenfeldt, A. (1943). New firms and free enterprise. Washington, D.C.: American Council on Public Affairs.

Parker, S. C., \& Robson, M. T. (2004). Explaining international variations in self-employment: Evidence from a panel of OECD Countries. Southern Economic Journal, 71, 287-301. https://doi.org/10.2307/4135292

Reynolds, P., Miller, B., \& Maki, R. (1995). Explaining regional variation in business births and deaths: U.S. 1976-1988. Small Business Economics, 7, 389-407.

https://doi.org/10.1007/BF01302739

Reynolds, P., Storey, D., \& Westhead, P. (1994). Cross-national comparisons of the variation in new firm formation rate. Regional Studies, 28(4), 443-456.

https://doi.org/10.1080/00343409412331348386

Santarelli, E., \& Tran, H. T. (2012). Growth of incumbent firms and entrepreneurship in Vietnam. Growth and Change, 43(4), 638-666.

https://doi.org/10.1111/j.1468-2257.2012.00601.x

Sutaria, V., \& Hicks, D. A. (2004). New firm formation: Dynamics and determinants. The Annals of Regional Science, 38, 241-262. https://doi.org/10.1007/s00168-004-0194-9

Thurik, R., Carree, M., van Stel, A., \& Audretsch, D. (2008). Does self-employment reduce unemployment? Journal of Business Venturing, 23, 673-686.

https://doi.org/10.1016/j.jbusvent.2008.01.007

Wenekers, S., Stel, A. V., Thurik, R., \& Reynolds, P. (2005). Nascent entrepreneurship and the level of economic development. Small Business Economics, 24(3), 293-309.

https://doi.org/10.1007/s11187-005-1994-8

Wennerkers, S., \& Thurik, R. (1999). Linking entrepreneurship and economic growth. Small Business Economics, 13(1), 27-55. https://doi.org/10.1023/A:1008063200484

\section{Copyright Disclaimer}

Copyright for this article is retained by the author(s), with first publication rights granted to the journal.

This is an open-access article distributed under the terms and conditions of the Creative Commons Attribution license (http://creativecommons.org/licenses/by/3.0/). 